\title{
Fibrous dysplasia of the maxilla: a case report
}

\author{
SOUSA, R. C. ${ }^{1}$, TAVARES, R. M. C. ${ }^{1}$ and LINS, C. C. S. A. ${ }^{2 *}$ \\ ${ }^{1}$ Universidade Federal de Pernambuco - UFPE, Avenida Moraes Rego, 1235, Cidade Universitaria, \\ CEP 50670-901, Recife, PE, Brazil \\ ${ }^{2}$ Department of Anatomy, Universidade Federal de Pernambuco - UFPE, Avenida Moraes Rego, 1235, \\ Cidade Universitaria, CEP 50670-901, Recife, PE, Brazil \\ *E-mail: rcsillaz@gmail.com; cabralcarlal@hotmail.com
}

\begin{abstract}
Introduction: Fibrous dysplasia is a benign bone lesion characterized by replacement of normal bone by fibrous connective tissue, and its diagnosis is based on clinical, radiological and histological findings. Objective: The aim of this study was to report a case of unilateral fibrous dysplasia in the maxilla, in the palate region, by using computed tomography. Results: On examination it was observed: a nodular lesion, with similar staining to the palatal mucosa with varicosities, regular edges, firm and painless. The radiographic findings on computed tomography showed one diffuse and heterogeneous thickening of the bony elements involving the hard palate extending to the posterior wall of the maxillary antrum. We opted for the proservation of the case, considering the age of the patient, the absence of facial asymmetry and lack of aesthetic and functional impairment. Conclusion: Thus, we emphasize that the knowledge of morphological changes is important for the diagnosis of bone pathologies, and the dentist must be familiar with the normal morphology of the structures and their possible abnormalities.
\end{abstract}

Keywords: maxillary, monostotic fibrous dysplasia, radiography.

\section{Introduction}

Fibrous dysplasia (FD) is a benign bone lesion characterized by replacement of normal bone for fibrous connective tissue, it shows different degrees of bone metaplasia. It is a development problem in which the primary fibrous tissue gradually expands, replacing the bone (OZEK, GUNDOGAN, BILKAY et al., 2002). It can be classified in two types: monostotic (when involving only one bone) and polyostotic (multiple bones), in both forms there is an involvement of the craniofacial bones in about half of cases (VALENTINI, CASSONI, MARIANETTI et al., 2009).

The monostotic form affects only one bone and corresponds to $70-80 \%$ of FD cases. The polyostotic form, in which multiple bones are affected, can be subdivided in three types: craniofacial, in which only the bones of the craniofacial complex are involved including the mandible and maxilla; Lichtenstein-Jaffe, which has similar involvement of multiple bones of the skeleton but has in addition "café-au-lait" spots in the skin; Albright syndrome, characterized by involvement of multiple bones, "café-au-lait" spots in the skin and endocrine impairment, especially early puberty in girls. The polyostotic form corresponds to $20-30 \%$ of cases (PONTUAL, TUJI, YOO et al., 2004). The bones commonly involved are the maxilla and frontal. When the maxilla is affected, other adjacent bones: zygomatic, sphenoid, frontal and nasal, are often also involved and therefore it is not strictly the monostotic one. When the frontal bone is compromised, it is common the involvement of the: sphenoid, temporal and zygomatic bones, and in most cases, are painless lesions (POSNICK, 1998).

Its diagnosis is based on clinical, radiological and histological findings. The signs and symptoms depend on the area involved. In the head and neck region, the abnormal bone growth can cause facial asymmetry and deformities, it might also cause nasal obstruction, sinusitis, hearing loss, headache and diplopia as well (RICALDE and HORSWELL, 2001).

Fibrous dysplasia can be studied with x-ray, scintigraphy, Magnetic Resonance Imaging (MRI) and Computed Tomography (CT scan), however by using radiographies is more difficult to assess due to the overlapping of anatomical structures and variety of image aspect (LISLE, MONSOUR and MASKIELL, 2008). The most common radiographic aspect is the appearance of frosted glass, with ill-defined margins, which is difficult to distinguish from normal bone (PERDIGÃO, PIMENTA, CASTRO et al., 2004). Thus, tomography is the exam for first investigation of patients with clinical suspicion of fibrous dysplasia. (LISLE, MONSOUR, MASKIELL, 2008) and has been the most widely used imaging method for the diagnosis of FD to show the extent and radiodensity that the pathology takes; it also assists in planning conservative treatments (MACDONALD-JANKOWSKI, YEUNG, LI et al., 2004). Clinical suspicion leads to the need for research with radiological examinations. A CT scan may suggests the diagnosis without biopsy. The exam shows three forms of manifestations: Sclera (compact): most common (50\%), typical sign of frosted glass between diploe; Lithic: radiolucent; pseudo-pagetic (pagetoid): a mix of the two previous forms. MRI is used to verify the neural involvement and provide more information about the injury. The skeleton scintigraphy with technetium is important for staging the involvement of multiple bones. Histological examination does clarify the certainty of the diagnosis (ALONSO, MATUSHITA and ALESSI, 2014). Thus, this study aimed to relate a case of fibrous dysplasia of the maxilla, at right side of the palate. 


\section{Relate of Case}

J.C.H.M.D., 29, leucoderma female patient, attended to the dentist in private practice, complaining of a palatal swelling on the right side in the first molar region, that measured around three centimeters of extension. During the clinical examination, it was observed the absence of right first molar, and in the palate, a nodular lesion, with similar pigmentation of the palatal mucosa with varicosities, regular edges, firm and painless (Figure 1). The patient had no facial asymmetry and the adjacent teeth did not have any mobility.

On computed tomography there was a diffuse and heterogeneous thickening of the bony elements involving the hard palate extending to the posterior wall of the maxillary antrum, as well as impairment of the medial and lateral pterygoid plates on the right side (Figure 2,3). That area is well defined in the maxilla by the plane of the anterior nasal spine with no evidence of cortical disruption or soft tissue components (Figure 4). Even though changes were observed in trabecular bone density on the left side of the maxilla, which demonstrates that the injury had reached this region, no clinical change in the morphology was visible on that side.

Other aspects were observed: secretion and/or thickening of the maxillary sinus, infratemporal and pterygopalatine fossae tomography with normal aspect, other maxillary sinuses with volume and normal aspects, orbits with normal appearance, adipose muscle planes of the nasopharynx and parapharyngeal space with attenuation values preserved. Thus, it was chosen the proservation of the case, considering the age of the patient, the absence of facial asymmetry and lack of aesthetic and functional impairment. The biopsy was not performed due to the risk of pathological fractures and the clinical and radiological findings had been very conclusive for fibrous dysplasia, unfortunately the patient had not returned for clinical and radiological exams for further evaluation.

\section{Discussion}

The fibro-osseous lesions (FOLs) represent a group of processes that are characterized by replacement of normal bone tissue by fibrous tissue containing a mineralized newly formed material called osteoid or cementoid due to the similarity to normal bone or cementum. The FOLs are classified as cemento-osseous dysplasia, fibrous dysplasia and ossifying fibroma. The histopathological features may be very similar in lesions with different cause, behavior and prognosis (BARNES, EVESON, REICHART et al., 2005; NEVILLE, DAMM, ALLEN et al., 2004).

The differential diagnosis between these lesions are based on clinical and radiographic characteristics, since the histopathological examination often shows up inconclusive (MACDONALD-JANKOWSKI, 2009). The treatment varies from proservation to the total removal of the lesion (NEVILLE, DAMM, ALLEN et al., 2004).

Von Recklinghausen in 1891, called "general osteitis fibrosa" (GENERAL Fibrous OSTEITIS?) pathological conditions represented by deformities and bone changes. However, the term FD was originally used by Thoma in 1954, being first described in 1938 by Lichtenstein and Jaffe (SANTOS, VIEIRA, GÓIS FILHO et al., 2010; SIMONATO, SANTOS, TAKANO et al., 2009).

This tissue change entails formation of osteolytic lesions, deformities and fractures (ATALLA, HALLACK NETO,



Figure 1. Occlusal view showing the swelling of the hard palate on the right side.



Figure 2. Axial section of computed tomography showing involvement of the right pterygoid process of the sphenoid bone.

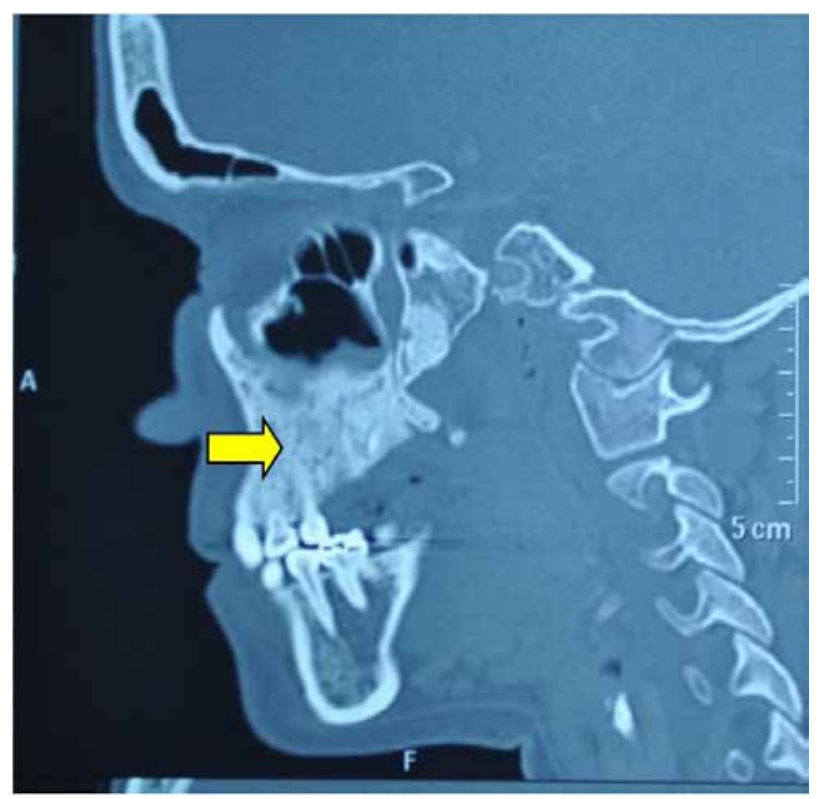

Figure 3. Sagittal computed tomography highlighting alteration of trabecular bone of the right maxilla. 


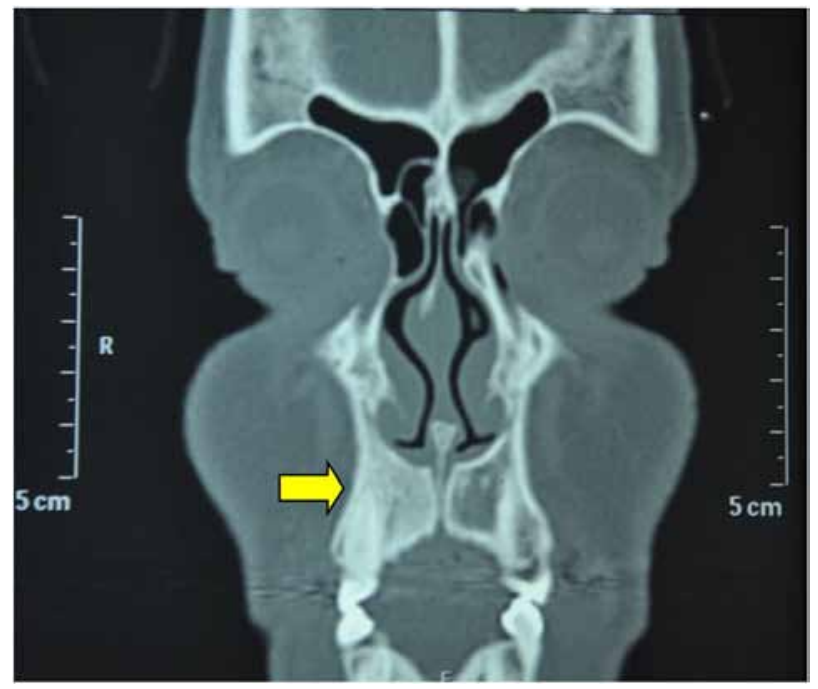

Figure 4. Coronal computed tomography indicating increased bone density in the right maxilla.

GOLLNER et al., 2010; SIMONATO, SANTOS, TAKANO et al., 2009). It is a benign condition characterized by replacement of bone by disorganized fibrous tissue and immature bone which, histologically, has numerous degrees of metaplasia (ADBELKARIM, GREEN, STARTZELL et al., 2008). This term was given pretending to indicate the condition represented a dysplastic growth resulting from disorganized mesenchymal cell activity, or a defect in the control of bone cell activity. A genetic defect involving Gs $\alpha$ protein seems to support this process, affecting the proliferation and differentiation of fibroblasts / osteoblasts what comprises these lesions (REGEZI, SCIUBBA and JORDAN, 2012).

The FD can be divided into three variants: monostotic, polyostotic and craniofacial. Despite that, some authors suggest five subgroups, as presented: Group I - monostotic-; Group II - polyostotic-; Group III - polyostotic - associated to Jaffe syndrome ; Group IV - polyostotic - associated with McCune-Albright syndrome (MAS); and group $\mathrm{V}$ - craniofacial - limited to maxillofacial complex (REICHART and PHILIPSEN, 2004).

The clinical consequences of the disease will depend on when and at what stage of cell proliferation the mutation occurred. Alterations during embryonic development will lead to polyostotic fibrous dysplasia and McCune-Albright syndrome. This last occurs in an early embryonic period, whereas monostotic fibrous dysplasia happens due to mutation in postnatal life during childhood, adolescence or adulthood (COHEN and HOWELL, 1999).

The monostotic form affects more the facial bones, especially the jaw, may also arise in the ribs, femur, tibia and mandible (DAL CIN, SCIOT, BRYS et al., 2000; PEREIRA JUNIOR and PEREIRA, 2010; PAGOTTO and MARIANI, 2009), and it is never associated with a syndrome (SIMONATO, SANTOS, TAKANO et al., 2009). They are usually unilateral lesions located in the posterior maxilla, and may present involvement by contiguity in the adjacent bones (ANTUNES, ROMUALDO FILHO and ANTUNES, 2004; NEVILLE, DAMM, ALLEN et al., 2004).

The signs and symptoms are closely related to their evolution and the bones involved. When they are present, the main symptoms reported by patients are: throbbing or discomfort, diplopia, warmth at the site of injury, decreased visual acuity, leading even to loss of vision, deafness, dizziness, and nasal obstruction (SANTOS, VIEIRA, GÓIS FILHO et al., 2010).

Its slow growth can bring several complications, such as facial asymmetry, chronic sinusitis, recurrent headache, nasal obstruction, retention and dental malocclusion. The presence of ulceration and involvement of cranial nerves is rare but can be found, causing paralysis due to the narrowing of foramina (LISLE, MONSOUR and MASKIELL, 2008; MARTINS, FREDDO, GOMES et al., 2010).

The main differential diagnosis should be made in relation to cemento-ossifying fibroma presenting the same histological characteristics of fibrous dysplasia. Nevertheless, the first one presents a radiographic image encapsulated with a radiolucent halo delimiting the lesion unlike fibrous dysplasia that features frosted glass appearance and ill-defined margins (PERDIGÃO, PIMENTA, CASTRO et al., 2004). Differential diagnosis also can be made with osteosarcoma, an alteration found in the pelvis, femur, humerus, the skull and facial bones. Radiographic signs would be the expansive soft tissue components, aggressive osteolysis, cortical rupture and extensive periosteal proliferation (JOSÉ, PERNAMBUCO and AMARAL, 2008). Futhermore, Paget's disease is characterized by high alkaline phosphatase levels and the involvement is bilateral while fibrous dysplasia is predominantly unilateral.

Fibrous dysplasia has a predilection to arise in women in the first two decades of life and stabilizes after puberty (ALVES,CANAVARROS, VILELA et al., 2002; PAGOTTO and MARIANI, 2009). In contrast, other authors stated that the monostotic form shows an equal distribution between genders (NEVILLE, DAMM, ALLEN et al., 2004; REGEZI, SCIUBBA and JORDAN, 2012).

The signs and symptoms observed in the case presented corroborate those described in the literature, such as: predilection for women in the second decade of life, increased volume, lesion without ulceration and hard to palpation, asymptomatic, unilateral, located in the posterior maxilla and involvement of the adjacent bones. Clinically, the lesion was observed on the right side, but the computed tomography observed changes of the trabecular bone and density of the left maxilla, thus suggesting extension to that side.

\section{Conclusion}

Fibrous dysplasia acting on the craniofacial region is responsible for functional and aesthetic repercussions. It affects young people and has a benign feature. Usually the growth is slow and asymptomatic, but according to its location, can invade and cause compression of important structures in the base of the skull and orbit.

The knowledge of the structural changes is important for the correct diagnosis of bone pathology and, the dental surgeon should be familiar with the normal morphology of the structures and their possible abnormalities. Most of the time, in the fibrous dysplasia, is observed an increase in size and facial asymmetry, even though it is necessary a thorough anatomical knowledge of the maxillo-facial region, and correlate them with the functions of the structures and the symptoms found in patients to determine which location is affected. The anatomical knowledge has a fundamental importance, not only in relation to the diagnosis of pathology, but also in 
reconstructive surgeries, ostectomies and osteoplastias, since many lesions have functional and aesthetic impairment.

\section{References}

ADBELKARIM, A., GREEN, R., STARTZELL, J. and PREECE, J. Craniofacial polyostotic fibrous dysplasia: a case report and review of literature. Oral Surgery, Oral Medicine, Oral Pathology, Oral Radiology, and Endodontics, 2008, vol. 106, n. 1, p. 49-55.

ALONSO, N., MATUSHITA, H. and ALESSI, MS. Abordagem cirúrgica no tratamento da displasia fibrosa craniofacial: experiência de 14 anos. Revista Brasileira de Cirurgia Plástica, 2014, vol. 29, n. 1, p. 66-70

ALVES, AL., CANAVARros, F., VILELA, DS., GRANATO, L. and PRÓSPERO, JD. Displasia fibrosa: relato de três casos. Revista Brasileira de Otorrinolaringologia, 2002, vol. 68, n. 2, p. 288-292.

ANTUNES, AA., ROMUALDO FILHO, J. and ANTUNES, AP. Displasia Fibrosa Óssea: Estudo retrospectivo - revisão de literatura. Revista Brasileira de Cirurgia de Cabeça e Pescoço, 2004, vol. 33, n. 1, p. 21-26.

ATALLA, A., HALLACK NETO, AE., GOLLNER, AM., FROSONI, DJ., REZENDE JÚNIOR, JG., SOUSA, FS., MATA, GF., FROSONI, DJ. and PASSOS, AS. Displasia Fibrosa: relato de caso e revisão de literatura. Revista Médica de Minas Gerais, 2010, vol. 20, n. esp, p. 399-403.

BARNES, EL., EVESON, JW., REICHART, P. and SIDRANSKY, D. Pathology and genetics of head and neck tumours. Lyon: IARC Press, 2005. 430 p.

COHEN, MM. and HOWELL, RE. Etiology of fibrous dysplasia and $\mathrm{Mc}$-Cune-Albright syndrome. International Journal of Oral and Maxillofacial Surgery, 1999, vol. 28, n. 5, p. 366-371.

DAL CIN, P., SCIOT, R., BRYS, P., DE WEVER, I., DORFMAN, H., FLETCHER, CD., JONSSON, K., MANDAHL, N., MERTENS, F., MITELMAN, F., ROSAI, J., RYDHOLM, A., SAMSON, I., TALLINI, G., VAN DEN BERGHE, H., VANNI, R. and WILLEN, $\mathrm{H}$. Recurrent chromosome aberrations in fibrous dysplasia of the bone: a report of the CHAMP study group. Chromosomes and morphology. Cancer Genetics and Cytogenetics, 2000, vol. 122, n. 1, p. 30-32.

JOSÉ, FF., PERNAMBUCO, ACA. and AMARAL, DT. Doença de Paget do osso. Einstein (Sao Paulo, Brazil), 2008, vol. 6, supplement 1, p. S79-S88.

LISLE, DA., MONSOUR, PA. and MASKIELL, CD. Imaging of craniofacial fibrous dysplasia. Journal of Medical Imaging and Radiation Oncology, 2008, vol. 52, n. 4, p. 325-332.

MACDONALD-JANKOWSKI, D. Fibrous dysplasia: a systematic review. Dento Maxillo Facial Radiology, 2009, vol. 38, n. 4, p. 196-215.

MACDONALD-JANKOWSKI, DS., YEUNG, R., LI, TK. and LEE, KM. Computed tomography of fibrous dysplasia. Dento Maxillo Facial Radiology, England, 2004, vol. 33, n. 2, p. 114-118.
MARTINS, CAM., FREDDO, AL., GOMES, FV. and SANT'ANNA FILHO, M. Displasia fibrosa monostótica: um desafio terapêutico. Odontologia Clínico-Científca, 2010, vol. 9, n. 4, p. 385-388

NEVILLE, BW., DAMM, DD., ALLEN, CM. and BOUQUOT, JE. Patologia oral \& maxilofacial. Rio de Janeiro: Guanabara Koogan, 2004. 798 p.

OZEK, C., GUNDOGAN, H., BILKAY, U., TOKAT, C., GURLER, T. and SONGUR, E. Craniomaxillofacial fibrous dysplasia. The Journal of Craniofacial Surgery, 2002, vol. 13, n. 3, p. 382-389.

PAGOTTO, LEC. and MARIANI, PB. Displasia fibrosa monostótica da maxila: revisão da literatura e relato de dois casos. Revista de Cirurgia e Traumatologia Buco-Maxilo-Facial, 2009, vol. 9, n. 2, p. 23-32.

PERDIGÃO, PF., PIMENTA, FJGS., CASTRO, WH., DE MARCO, L. and GOMEZ, RS. Investigation of the Gs_ gene in the diagnosis of fibrous dysplasia. International Journal of Oral and Maxillofacial Surgery, 2004, vol. 33, p. 498-501

PEREIRA JUNIOR, AJA. and PEREIRA, FL. Displasia fibrosa monostótica: relato de caso de uma recidiva. Revista Brasileira de Cirurgia Buco-Maxilo-Facial, 2010, vol. 10, n. 1, p. 63-68.

PONTUAL, ML., TUJI, FM., YOO, HJ., BÓSCOLO, FN. and ALMEIDA, SM. Estudo epidemiológico da displasia fibrosa dos maxilares numa amostra da população brasileira. Odontologia ClínicoCientifica, 2004, vol. 3, n. 1, p. 25-30.

POSNICK, JC. Fibrous dysplasia of the craniomaxillofacial region: current clinical perspectives. British Journal of Oral \& Maxillofacial Surgery, 1998, vol. 36, n. 4, p. 264-273.

REGEZI, JA., SCIUBBA, JJ. and JORDAN, RCK. Patologia oral: correlações clínicopatológicas. Rio de Janeiro: Elsevier, 2012. 407p.

REICHART, PA. and PHILIPSEN, HP. Odontogenic tumors and allied lesions. London: Quintessence, 2004. p. 281-291.

RICALDE, P. and HORSWELL, B. Craniofacial fibrous dysplasia of the fronto-orbital region: a case series and literature review. Journal of Oral and Maxillofacial Surgery, 2001, vol. 59, n. 2, p. 157-167.

SANTOS, JN., VIEIRA, TSLS., GÓIS FILHO, DM., VASCONCELOS, SJA. and AZVEDO, RA. Displasia fibrosa: osteoplastia com acesso Weber-Ferguson: relato de caso. Revista de Cirurgia e Traumatologia Buco-Maxilo-Facial, 2010, vol. 10, n. 1, p. 73-80.

SIMONATO, LE., SANTOS, CA., TAKANO, RY., SOUBHIA, AMP. and MIYAHARA, GI. Displasia fibrosa monostótica: relato de caso com acompanhamento clínico/radiográfico de 10 anos. Revista Salusvita, 2009, vol. 28, n. 1, p. 73-84.

VALENTINI, V., CASSONI, A., MARIANETTI, TM., TERENZI, V., FADDA, MT. and IANNETTI, G. Craniomaxillofacial fibrous dysplasia: conservative treatment or radical surgery? A retrospective study on 68 patients. Plastic and Reconstructive Surgery, 2009, vol. 123 , n. 2 , p. $653-660$. 